\title{
THE REALIZATION OF IDEATIONAL MEANINGS IN THE STUDENTS' RECOUNTS ${ }^{1}$
}

\section{Sri Mulatsih ${ }^{2}$}

Abstract: English Department Students of Faculty of Languages and Letters of Dian Nuswantoro University usually have difficulties in writing English Texts. Those difficulties deal with the way to organize ideational meaning in their texts. Based on that fact, this study was conducted to know the realization of ideational meaning in the students' texts, especially recounts. The data were taken from the students' recounts, and for the sake of this study, 10 recounts were chosen as the data. To analyze the data, Halliday and Matthiessen's framework (1999) was applied to get a deep understanding of Ideational Meaning. The result shows that in organizing the Ideational Meanings in their recounts, the students used sequences, figures, the elements of figures: Process, Participant, and Circumstances; and the realization of those elements in lexicogrammar. Kinds of sequences (clause complexes) the student mostly made in their recount are enhancement, and extension. Elaboration. locution or idea have lower portion compared to the two sequences mentioned above. Four kinds of figures are found in the students recounts. Those are figure of doing (material and behavioral processes), figure of sensing (mental process), figure of saying (verbal process), and figure of being (relational: attributive, identifying) process, and existential process). Among the four figures mentioned above, figures of doing (material processes) with actor and goal as the key participants dominate in all texts. 112 circtimstances (circumstances of time, place, manner, matter, and accompaniment) are found in the students' recounts. Those

A Case Study conducted at the English Department of the Faculty of Languages and Letters of Dian Nuswantoro University, Semarang.

2 Dra. Sri Mulatsih, M.Pd. <asihpnrg@yahoo.com> is a lecturer of the Faculty anguages and Letters of Dian Nuswantoro University, Semarang. 
circumstances are realized in simple and macro circumstances. The number of macro circumstances is higher than that of simple ones. Since personal recount is a text telling someone's past experience, the realization of participants in their recounts are mostly conscious simple things. Simple qualities only exist in relational (attributive) process. The processes are mostly realized in polar non- phrasal verbs in past tense.

Key words: ideational meaning, recount, process, participant, circumstance.

\section{INTRODUCTION}

Writing text is not easy because text is not just several words that are put together without any grammars but text is a language that is functional. That is language that is doing some jobs in some context. So any instance of living language that is playing some part in a context of situation is called a text. It may be spoken or written, or indeed in any other medium of expression that we like to think of (Halliday and Hasan, 1985:10). Thus, we cannot simply treat a theory of text as an extension of grammatical theory, and set up formal systems for deciding what a text is. It is by no means easy to move from the formal definition of a sentence to the interpretation of particular sentences of living language; and this problem is considerably greater in the case of the text. Because of its nature as a semantic entity, a text, more than a linguistic unit, is to be considered from two perspectives at once, both as a product and as a process.

The text is a product in the sense that it is an input, something that can be recorded and studied, having a certain construction that can be represented in systematic terms. It is a process in the sense of a continuous process of semantic choice, a movement through the network of meaning potential, with each set of choices constituting the environment for a further set.

Writing, like speaking, is a productive language skill. The students cannot be good writers unless they practice writing and learn to organize expressions they choose to make their points precisely. They need to experiment with the language, playing with words and manipulating phrases and sentences. The more they play with language, the more they will 
be able to control it. So the teacher must let the students explore and experiment the language. The first time they put words together may not be right, but if they do exercises carefully and creatively they can be expected to become good writers. Writing as one of the four language skills is regarded to be the most complex ability to be acquired by the EFL leamer. Lewitt (1990:17-23) in English Teaching Forum also admits that writing is clearly a complex process, and competent writing is frequently accepted as being the last language skill to be acquired. This becomes problematic in English Curriculum as all the four language skills must be taught to the leamer from the early stage of their writing. It means that writing skill is practiced at the same time the students have to acquire the other skills.

In writing, the students are required to produce language to express their ideas. To do this, they should have sufficient knowledge of what to write and about the organization of language. Knowing what to write will enable the students to know the flow of ideas, whereas knowing how to organize will help them convey the ideas in a clear way to the readers. To produce good writing, it is necessary for the students to know how to organize the message of their writing.

In the English Department, Faculty of Languages and Letters, Dian Nuswantoro University, Writing course is given for three semesters. Writing 1 , sentence-based writing, is given in the first semester; Writing 2 , paragraph- based writing, is given in the second semester; and Writing 3 , genre-based writing, is given in the third semester. In Writing 3 , the students are asked to write several types of text, and one of them is recount.

Recount is a text type which reconstructs past experience. A recount is the unfolding of a sequence of events over times (Derewianka, 1995:14). In writing recounts, students usually tell their past experience. They tell what had happened in their past events. The Ideational meanings in their recounts, which are representations of experiences, are organized by clauses. Based on the statement above the writer is interested in analyzing the message (ideational meaning) organization in the students' recounts. 


\section{THEORETICALFRAMEWORK OF IDEATIONALMEANING}

This framework describes the ideation base that is how the phenomena of our experience are construed as categories and relationships of meaning. For greater clarity, the system network of ideation base is introduced and built up in a number of the following steps (Halliday and Matthiessen, 1999:48 65):

1. Phenomena: A phenomenon is the most general experiential category that is anything that can be construed as part of human experience. The phenomena of experience are of three orders of complexity: complex (a complex of figures i.e. a sequence), configurational (configuration of elements, i.e. figure), and elementary (a single element).

2. Sequences: A sequence is a series of related figures. Consequently, sequences are differentiated according to the kinds of relations figures can enter temporal ( $x$ happened, then $y$ happened, etc.), causal ( $x$ happened, so $y$ happened etc.) and so on. In any pair of figures related in sequence, one figure may (i) expand the other, by reiterating it (elaboration), by adding it (extension) or by qualifying it (enhancement); or (ii) project (report, quote) the other by saying it (locution) or thinking it (idea).

3. Figures: A figure is a representation of experience in the form of a configuration, consisting of a process, participants taking part in this process and associated circumstances. According to Halliday and Matthiessen (1999:52) there are four types of figures: being, doing, sensing, and saying. Then each figure may be either projected (by another figure) or not. If it is projected, it may be an idea or locution.

4. Elements: Elements fill the roles of figures. Participant roles are filled by participants (things or qualities), circumstance roles by circumstances (times, places, causes, etc.), and the process roles by a process.

a. Participants

Participant roles in figures are filled by elements of the type "participant"; they are phenomena capable of 
taking on a participant role in a process of configuration, e.g. bringing it about or being affected by it. They are differentiated according to two parameters: macro and simple. Macro participants are all metaphorical and will be left out in this consideration. Simple participants may be things or qualities.

b. Circumstances

Circumstances fill circumstantial roles in figures. Circumstances are either "simple or macro". Simple circumstances are those that only consist of one word, and the most usual, are those of time, place, mannerqualities and intensity, all of which are circumstances of enhancements. Macro circumstances are those which are made up of a special type of figure having another participant inside it.

c. Processes

Processes serve in the most central or nuclear in a figure; they embody the temporal properties of a figure unfolding in time. The process element is either polar (positive/ negative) or modal (some intermediate degree between positive and negative); it may embody phase, or aspect; and it will refer to past, present, or future time.

This framework was used to describe the realization of ideational meanings in a text. In this study, it was used to know the realization of Ideational meanings in the students' recounts.

\section{RESEARCH METHODOLOGY}

This research is a descriptive qualitative one. It describes the ideational meanings in the students' recounts. In this research the data were collected using documentation technique. They were in the form of the students' writing especially recounts. The students' recounts were obtained from the writing tasks that were given to them. The data are the natural ones. There were about 50 students who were asked to write recounts. And for the 
sake of this research, purposive random sampling was used to obtain 10 students' recounts as the sample of this research. Those 10 recounts were chosen by considering that they are personal recounts and they have correct schematic structure of recount that is orientation, record of events, and reorientation.

After the data were collected they were then analyzed. The technique of data analysis in this research was based on Halliday and Matthiessen's framework) above. While the steps to analyze the data are as follows: reading each of the students' recounts; dividing each recount into sequences; dividing each sequence into figures (clauses); classifying the figures (clauses) based on its elements: process, participants, and circumstances; and describing the realization of elements of participants, processes, and circumstances in wordings.

\section{FINDINGSAND DISCUSSION}

\section{A. The sequences in the students' recounts}

As mentioned in the theoretical framework, sequences are realized in clause complexes, that is two or more clauses logically connected. They are combined through one of two logico-semantic relations, which are expansion or projection. Expansion is divided into elaboration, extension, and enhancement, while projection is divided into locution or idea. The kinds and the number of sequence found in the students' recounts can be seen in table 1 below:

\begin{tabular}{|c|c|c|c|c|c|c|c|c|c|c|c|c|}
\hline \multirow[t]{2}{*}{ NO } & \multicolumn{2}{|c|}{ SEQUENCES } & \multicolumn{10}{|c|}{ TEXT } \\
\hline & & & 1 & 2 & 3 & 4 & 5 & 6 & 7 & 8 & 9 & 10 \\
\hline \multirow[t]{3}{*}{1} & \multirow{3}{*}{ Expansion } & Elaboration & 1 & 2 & 0 & 0 & 1 & 0 & 0 & 2 & 1 & 0 \\
\hline & & Extension & 2 & 2 & 3 & 1 & 10 & 2 & 1 & $\overline{5}$ & 2 & $\overline{4}$ \\
\hline & & Enhancement & 2 & 7 & 6 & 12 & 4 & 7 & 6 & 3 & $\overline{5}$ & 9 \\
\hline \multirow[t]{2}{*}{2} & \multirow[b]{2}{*}{ Projection } & Locution & $\overline{0}$ & $\overline{0}$ & 1 & 0 & 2 & 1 & 0 & 0 & 0 & 0 \\
\hline & & Idea & 2 & 0 & 1 & 2 & 2 & 2 & 0 & 0 & $\overline{0}$ & 1 \\
\hline 3 & \multicolumn{2}{|c|}{ Simple sentences } & 7 & 4 & 10 & 3 & 5 & 15 & 11 & $\overline{5}$ & 5 & 5 \\
\hline
\end{tabular}

Table 1:

Sequences in the students' recounts 
Table 1 reveals that in organizing the Ideational meanings in their recounts, the students used sequences in the form of clause complexes and simple sentences. The number of clause complexes they produced is less than that of simple sentences. There are two kinds of clause complex produced, they are expansion and projection. Projection was rarely employed by the students. This does not mean they are not capable of producing projection, but it is because of the reason that in writing recounts, projection is not as important as in narratives. The examples of projection produced in their recounts are:

Ithought that my face was red at that time;

Ithought that Bali was a wonderful island.

Expansion is the other kind of clause complex produced by the students in their recounts. There are three kinds of expansion produced. They are elaboration, extension, and enhancement. Among the three kinds of expansion, enhancements are mostly produced. The example of enhancement produced by the student is:

After my 'angkot' reach Milo intersection, I should move to other 'angkot' to Karang Ayu.

Besides using clause complex, the students also used simple sentences in organizing the message in their recounts. Most of the simple sentences they produced do not have high lexical density. Their sentences used only simple subject, simple predicate, or even simple complement. There is not any nominal group found in their sentences but only single words. It shows that the students' ability in writing sentences is still low. The examples of the students' simple sentences are:

Unfortunately I had not brought my ID card:

On the next day I started my day as usual.

\section{B. The figures (clauses) in the students' recounts}

The following discussion covers the figures (clauses) across the 10 examined recounts written by the students. According to Halliday and Matthiessen (1999) there are four kinds of figures, figure of doing, figure of 
sensing, figure of saying, and figures of being. The figures made by the students can be seen in table 2 . The figures the students mostly made in their recounts are figures of doing (material process). This means that the activities in their recounts are centrally concerned with actions and events. This result shows that the students' understanding in writing recounts is good because it is in accordance with what the theory said, that is in writing recount the processes used are material. Besides figures of doing, there are also other kinds of figure found in the students' recounts such as figures of sensing (material process), figures of saying (verbal process), and also figures of being (relational process), but the number is not as big as the one of figures of doing (material process).

\begin{tabular}{|c|c|c|c|c|c|c|c|c|c|c|c|c|c|}
\hline \multirow[t]{2}{*}{ No } & \multirow{2}{*}{\multicolumn{2}{|c|}{ FIGURES }} & \multicolumn{10}{|c|}{ TEXT } & \\
\hline & & & 1 & 2 & 3 & 4 & 5 & 6 & 7 & 8 & 9 & 10 & \\
\hline \multirow[t]{2}{*}{1} & \multirow{2}{*}{$\begin{array}{l}\text { Figures of } \\
\text { Doing }\end{array}$} & Doing & 25 & 10 & 17 & 20 & 12 & 14 & 8 & 7 & 9 & 21 & 143 \\
\hline & & Behaving & 3 & 6 & 8 & 5 & 6 & 4 & 4 & 3 & 3 & 0 & 42 \\
\hline 2 & \multicolumn{2}{|c|}{ Figures of Sensing } & 2 & 2 & 1 & 2 & 2 & 2 & 7 & 6 & 4 & 4 & 32 \\
\hline 3 & \multicolumn{2}{|c|}{ Figures of Saying } & $\overline{0}$ & $\overline{0}$ & $\overline{0}$ & 0 & 5 & 3 & 0 & 1 & 2 & $\mathbf{0}$ & 11 \\
\hline \multirow[t]{2}{*}{4} & \multirow{3}{*}{$\begin{array}{l}\text { Figures } \\
\text { of Being }\end{array}$} & Identifying & $T$ & 0 & 0 & 0 & 2 & 3 & 0 & 3 & 0 & $\mathbf{0}$ & 9 \\
\hline & & Ascribing & 9 & $\overline{8}$ & 9 & 12 & 5 & 13 & 9 & 7 & 5 & 12 & 87 \\
\hline \multirow[t]{2}{*}{4} & & existing & 1 & 1 & 0 & 2 & 0 & $\mathbf{I}$ & $\overline{0}$ & 0 & 2 & 1 & 8 \\
\hline & \multicolumn{2}{|c|}{ TOTAL } & 44 & 27 & 34 & 39 & 33 & 41 & 29 & 28 & 25 & 38 & \\
\hline
\end{tabular}

Table 2:

Figures (clause) in the students' recounts

\section{Processes and Participants in the Students' Recounts}

There are six types of process found in the students' recounts. They are material, behavioral, mental, verbal, relational, and existential. Each process is followed by its participant. The kinds of process and the number of their participants can be seen in table 3 : 
S. Mulatsih, The Realization of Ideational Meanings in the Students'Recounts 151

\begin{tabular}{|c|c|c|c|c|c|c|c|c|c|c|c|c|}
\hline \multirow[t]{2}{*}{ NO } & \multirow[t]{2}{*}{ PROCESS } & \multirow{2}{*}{$\begin{array}{c}\text { PARTICIPANT } \\
\text { ROLES }\end{array}$} & \multicolumn{10}{|c|}{ TEXT } \\
\hline & & & 1 & 2 & 3 & 4 & 5 & 6 & 7 & 8 & 9 & 10 \\
\hline \multirow[t]{7}{*}{1} & \multirow[t]{4}{*}{ Material } & Actor & 24 & 15 & 13 & 14 & 11 & 14 & 11 & II & 7 & 20 \\
\hline & & Goal & 8 & 12 & 8 & 7 & 7 & 3 & 5 & 8 & $\overline{6}$ & 7 \\
\hline & & Recipient & 0 & 1 & $\mathrm{I}$ & $\overline{0}$ & 0 & 0 & 0 & 0 & 1 & 0 \\
\hline & & Inducer & 0 & 0 & I & 0 & 0 & 0 & $\mathbf{T}$ & 0 & 0 & 0 \\
\hline & \multirow[t]{3}{*}{ Behavioral } & Bchaver & 1 & 0 & 3 & 2 & 4 & 2 & 3 & 0 & 4 & 1 \\
\hline & & Range & 1 & 0 & 2 & 2 & 2 & 1 & 3 & 0 & 3 & 1 \\
\hline & & Targel & 0 & 0 & 0 & 1 & 0 & 0 & 0 & $\overline{0}$ & 0 & 0 \\
\hline \multirow[t]{2}{*}{2} & \multirow[t]{2}{*}{ Mental } & Senser & 5 & 5 & 2 & 5 & 4 & 2 & 3 & 7 & 1 & 3 \\
\hline & & Phenomenon & 3 & $\overline{3}$ & 2 & 1 & 2 & 0 & 3 & 5 & T & 2 \\
\hline \multirow[t]{3}{*}{3} & \multirow[t]{3}{*}{ Verbal } & Sayer & 0 & 0 & 1 & $t$ & 4 & 3 & 1 & 0 & 1 & 0 \\
\hline & & Receiver & 0 & 0 & 0 & 0 & 1 & 2 & 1 & $\overline{0}$ & 1 & 0 \\
\hline & & Verbiage & 0 & 0 & 0 & 0 & 1 & 0 & 0 & 0 & 2 & 0 \\
\hline \multirow[t]{6}{*}{4} & \multirow{2}{*}{$\begin{array}{l}\text { Relationa] } \\
\text { (Attributive) }\end{array}$} & Carrier & 10 & 9 & II & 14 & 7 & 12 & 10 & 8 & 6 & 11 \\
\hline & & Attribute & 9 & 6 & 9 & 12 & 6 & 9 & 10 & 6 & 6 & 10 \\
\hline & \multirow{2}{*}{$\begin{array}{l}\text { Relational } \\
\text { (Identifying) }\end{array}$} & Token & 1 & 0 & 0 & 0 & 2 & 3 & 0 & 2 & 0 & 0 \\
\hline & & Valuc & 1 & 0 & 0 & 0 & 2 & 3 & 0 & 2 & 0 & 0 \\
\hline & Existential & Existent & 1 & I & 0 & 2 & 0 & 1 & 0 & 0 & 2 & 1 \\
\hline & \multicolumn{2}{|r|}{ Total } & $\overline{64}$ & 52 & 53 & 61 & 53 & 55 & 50 & 49 & 41 & 56 \\
\hline
\end{tabular}

Table 3:

Processes and participants in the students' recounts

Table 3 reveals that in line with the domination of material processes in the students' recounts, actors and goals become the key participants. Since the students' writings are in the form of recounts, that is the ones that tell about past experiences in certain places and times, circumstances of time and place are dominant in their recounts.

\section{Circumstances in the students' recounts}

Besides discussing the processes and participants, circumstances are also elements in figures in which the processes are held. Adverbial group or prepositional phrase typically realizes the circumstances. The kinds and 
number of circumstances found in the students' recounts can be summarized in table 4.

\begin{tabular}{|l|l|c|c|c|c|c|c|c|c|c|c|c|}
\hline \multirow{2}{*}{ NO } & CIRCUMSTANCES & \multicolumn{8}{|c|}{ TEXT } & \\
\cline { 3 - 11 } & & 1 & 2 & 3 & 4 & 5 & 6 & 7 & 8 & 9 & 10 & \\
\hline 1 & Time & 8 & 4 & 4 & 3 & 7 & 12 & 3 & 7 & 4 & 5 & 54 \\
\hline 2 & Place & 5 & 5 & 5 & 0 & 2 & 2 & 4 & 2 & 3 & 4 & 35 \\
\hline 3 & Manner & 0 & 4 & 3 & 3 & 2 & 5 & 0 & 0 & 0 & 3 & 20 \\
\hline 4 & Matter & 0 & 0 & 0 & 0 & 2 & 0 & 0 & 1 & 0 & 0 & 2 \\
\hline 5 & Accompaniment & 0 & 0 & 1 & 0 & 0 & 0 & 0 & 0 & 0 & 0 & 1 \\
\hline
\end{tabular}

Table 4:

Circumstances in the students' recount

E. The realization of participants in the students' recounts

This part focuses on the realization of participants in wordings. They are realized in nominal groups in the forms of simple things or qualities. Simple things usually exist in all process types, but simple quality usually exist in the process of relational (attributive). The number of simple things and qualities can be seen in table 5 , which shows that the students still found difficulties in making nominal groups, because the participants in their recounts usually consist of one word without any qualifiers or identifiers.

\begin{tabular}{|l|l|l|c|c|c|c|c|c|c|c|c|c|}
\hline \multirow{2}{*}{ NO } & \multicolumn{2}{|c|}{ PARTICIPANTS } & \multicolumn{10}{|c|}{ TEXT } \\
\cline { 3 - 13 } & \multicolumn{2}{|c|}{} & 1 & 2 & 3 & 4 & 5 & 6 & 7 & 8 & 9 & 10 \\
\hline 1 & $\begin{array}{l}\text { Simple } \\
\text { Thing }\end{array}$ & Conscious & 34 & 33 & 32 & 31 & 35 & 31 & 36 & 36 & 25 & 33 \\
\cline { 3 - 13 } & & $\begin{array}{l}\text { Non- } \\
\text { conscious }\end{array}$ & 24 & 16 & 17 & 21 & 15 & 19 & 6 & 11 & 12 & 19 \\
\hline 2 & Simple Quality & 6 & 3 & 4 & 9 & 3 & 5 & 8 & 2 & 4 & 4 \\
\hline & \multicolumn{2}{|c|}{ Total } & 64 & 52 & 53 & 61 & 53 & 55 & 50 & 49 & 41 & 56 \\
\hline
\end{tabular}

Table 5:

The Realization of Participants in the Students' Recounts 
S. Mulatsih, The Realization of Ideational Meanings in the Students'Recounts 153

F. The realization of processes in the students' recounts

As stated before, processes are realized in verbal groups. These groups are verbs either polar or modal, phasal or non-phasal, and and either in past, present, or future. The realization of processes in the students' recounts can be seen in table 6 , reveals that the realization of processes in the students' recounts are mostly past polar non-phasal verbs. The other realizations are present polar non-phasal verbs, past modal non-phasal verbs, and past polar phasal verbs. Past verbs mostly occured in series of events, and present verbs occurred in orientation, and reorientation. From this result, it can be said that in writing recounts, the students have already used the correct tense because based on the theory propoed by Derewianka, recounts must be dominated by past actions. One thing that the students must improve in making process is not tense, but the way they made verbal groups. They should make phasal verbs more than non-phasal verbs.

\begin{tabular}{|c|c|c|c|c|c|c|c|c|c|c|c|c|c|}
\hline \multirow[t]{2}{*}{ NO } & \multirow{2}{*}{\multicolumn{2}{|c|}{ PROCESS }} & \multirow[t]{2}{*}{ TENSE } & \multicolumn{10}{|c|}{$\overline{\text { TEXT }}$} \\
\hline & & & & 1 & $\overline{2}$ & 3 & 4 & 5 & 6 & 7 & 8 & 9 & 10 \\
\hline \multirow[t]{6}{*}{$T$} & \multirow[t]{6}{*}{ Polar } & \multirow[t]{3}{*}{ Phasal } & Past & 0 & 0 & 2 & 3 & $\overline{0}$ & $\overline{0}$ & 3 & $\overline{0}$ & 2 & 1 \\
\hline & & & Present & 0 & 0 & 0 & 1 & 0 & 0 & 0 & $\overline{0}$ & $\overline{0}$ & 1 \\
\hline & & & Future & 0 & 0 & 0 & 0 & 0 & 0 & 0 & 0 & $\overline{0}$ & $\overline{0}$ \\
\hline & & \multirow{3}{*}{$\begin{array}{l}\text { Non- } \\
\text { phasal }\end{array}$} & Past & 40 & $\overline{22}$ & 25 & 22 & 29 & 33 & $\overline{24}$ & 19 & 16 & 31 \\
\hline & & & Present & 1 & 6 & $\overline{8}$ & 10 & 5 & $\overline{4}$ & 2 & 7 & 4 & 4 \\
\hline & & & Future & 0 & $\overline{0}$ & o & $\overline{0}$ & $\overline{0}$ & $\overline{0}$ & $\overline{0}$ & $\overline{0}$ & 0 & $\overline{0}$ \\
\hline \multirow[t]{6}{*}{2} & \multirow[t]{6}{*}{ Modal } & \multirow[t]{3}{*}{ Phasal } & Past & 0 & 0 & o & 0 & $\overline{0}$ & $\overline{0}$ & 0 & 0 & $T$ & 0 \\
\hline & & & Present & 0 & 0 & 0 & 0 & $\overline{0}$ & 0 & 0 & 0 & $T$ & 0 \\
\hline & & & Funure & 0 & $\overline{0}$ & $\overline{0}$ & 0 & $\overline{0}$ & $\overline{0}$ & 0 & $\overline{0}$ & 0 & 0 \\
\hline & & \multirow{3}{*}{$\begin{array}{l}\text { Non- } \\
\text { phasal }\end{array}$} & Past & 2 & $\overline{0}$ & 3 & 0 & 1 & $\overline{0}$ & I & 1 & $\overline{0}$ & 0 \\
\hline & & & Present & 0 & $\overline{0}$ & 0 & 2 & 0 & $\overline{0}$ & $\overline{0}$ & 0 & $\overline{0}$ & 0 \\
\hline & & & Future & 0 & 0 & 0 & 0 & 0 & $\overline{0}$ & $\overline{0}$ & $\overline{0}$ & $\overline{0}$ & $\overline{0}$ \\
\hline
\end{tabular}

Table 6:

The realization of processes in the students' recounts 


\section{G. The realization of circumstances in the students' recounts}

As mentioned in table 4, there are 5 kinds of circumstances found in the students' recounts. They are circumstances of time, place, manner, matter, and accompaniment. In wordings those circumstances are realized whether they are simple and macro. The number of those circumstances can be seen in table 7:

\begin{tabular}{|c|l|c|c|c|c|c|c|c|c|c|c|c|}
\hline \multirow{2}{*}{ NO } & \multicolumn{1}{|c|}{$\begin{array}{c}\text { KINDS OF } \\
\text { CIRCUMSTANCE }\end{array}$} & \multicolumn{10}{|c|}{ TEXT } \\
\cline { 3 - 13 } & & 1 & 2 & 3 & 4 & 5 & 6 & 7 & 8 & 9 & 10 & \\
\hline 1 & Simple & 0 & 4 & 4 & 2 & 2 & 10 & 3 & 1 & 2 & 2 & 32 \\
\hline 2 & Macro & 13 & 9 & 8 & 4 & 9 & 9 & 4 & 8 & 5 & 10 & 80 \\
\hline
\end{tabular}

\section{Table 7:}

The Realization of Circumstances in the Students' Recounts

Table 7 shows that circumstances made by the students in their recounts are mostly realized by the macro ones. They are in the form of adverb phrases or prepositional phrases. Simple circumstances also occurred in the students' recounts, but they are not as many as macro ones. This fact shows that the students did not have difficulties in making circumstances.

\section{CONCLUSION}

Based on the findings and discussion in the previous chapter, it can be concluded that the Ideational meanings in the students' recounts are characterized by sequences, figures, processes, participants, and circumstances, and their realizations in wordings. The complete results of this research can be stated as follows:

The kinds of sequences (clause complexes) the student mostly made in their recount are enhancement, and extension. Elaboration, locution or idea have lower portion compared to the two sequences mentioned above. From the recounts under study, it can be said that the students still have some difficulties in making sequences because several simple clauses are still found in their texts. 
Four kinds of figures are found in the students recounts. Those are figure of doing (material and behavioral processes), figure of sensing (mental process), figure of saying (verbal process), and figure of being (relational: attributive, identifying) process, and existential process). Among the four figures mentioned above, figures of doing (material processes) the actor and goal become the key participants that dominate all texts. It means that the clauses in their recounts are centrally concerned on actions and events.

112 circumstances (circumstances of time, place, manner, matter, and accompaniment) are found in the students' recounts. Those circumstances are realized in simple and macro circumstances. The number of macro circumstances is higher than that of simple ones. It shows that the students can produce circumstances in more than one word in which there is a participant in it.

Since personal recount is a text, telling someone's past experience, the realization of participants in their recounts are mostly conscious simple things like $I$, you, we, Linda, etc. Simple qualities only exist in relational (attributive) process. The processes are mostly realized in polar non-phasal verbs in past tense and the students rarely made polar phasal verbs in their recounts.

\section{BIBLIOGRAPHY}

Arikunto, Suharsimi. Prosedur Penelitian: Suatu Pendekatan Praktek. Jakarta: PT. Rineka Cipta, 1996.

But, David et. al. Using Functional Grammar: An Explorer's Guide. Second Edition. Sydney: National Centre for English Language Teaching Research. Macquire University, 2001.

Derewianka, Beverly. Exploring How Text Work. Newtown: Primary English Teaching Association, 1995.

Eggin, Suzanne. An Introduction to Systemic Functional Linguistics. London: Printer Publishers, 1994.

Eggin, Suzanne and Diana Slade. Analyzing Casual Conversation. London: Casell, 1997.

Fairclough, Norman. Language and Power. London and New York: Longman, 1989. 
Gerot, L. and P. Wignel. Making Sense of Functional Grammar. Cammeray, New South Wales: Antipodean Educational Enterprises, 1994.

Guion, Lisa A. Triangulation: Establishing the Validity of Qualitative Studies. University of Florida: Extension. Institute of Food and Agriculture Scienes, 2002

Halliday, M.A.K. and R. Hasan. Language, Context, and Text: Aspects of Language in a Social Semiotic Perspective: Melbourne: Deakin Unibersity Press, 1985.

Halliday, M.A.K. Learning How to Mean. London: Edward Amold Ltd., 1975. Language as Social Semiotic: The Social Interpretation of Language and Meaning. London: Edward Amold, 1978.

- Spoken and Written Language. Geelong, Victoria: Deakin University Press, 1985.

. An Introduction to Functional Grammar. Second Edition. London: EdwardAmold, 1994.

Halliday, M.A.K. and C.M.I.M. Matthiessen. Construing Experience Through Meaning: A Language Based Approach to Cognition. London: Continuum, 1999.

Isaac, Stephen and William B. Michael. Handbook in Research and Evaluation. Sandiego: Edits Publishers, 1971.

Kress, J.R. Halliday: System and Function in Language. London: Oxford University Press, 1976.

Le Compte and Praissle. Ethnography and Qualitative Design in Educational Research, $Z^{\text {ed }}$ ed. California. Academic Press. Inc., 1993.

Lewitt, P.J. "How to Cook a Tasty Essay". English Teaching Forum. Vol. 26, 1990: 1723.

Malmkjaer, Kriste. The Linguistic Encyclopedia. New York: Routledge, 1995. Martin, J.R., C.M.I.M. Matthiessen, and C. Painter. Working with Functional Grammar. London: Amold, 1997.

Martin, J.R. and D. Rose. Working with Discourse. Meaning Beyond the Clause. London: Arnold, 2003.

Matthiessen, C.M.1.M. Lexicogrammatical Cartography: English System. Tokyo: International Language Science Series, 1995.

Miller, Tom. Functional Approach to Written Text: Classroom Application. Washington, DC: English Language Program United States Information Agency, 1997.

Puspitasari, Florentina Unggul. "Transitivity Analysis of 'My Lost Love Found" Short Story". Unpublished Thesis Semarang : Dian Nuswantoro University, 2005. 
S. Mulatsih, The Realization of Ideational Meanings in the Students'Recounts 157

Randaccio. Some Notes on Systemic- Functional Linguistics. www.public.jastate. edu carole/LING511/sfl.html, retrieved on October 2006

Schriffin, D. Approaches 1o Discourse. Oxford: Blackwell, 1995.

Ventola, Eija. The Structure of Casual Conversation in English. In Journal of Pragmatics. 1979: 267298. 